\title{
Incidence of Post-Harvest Fungal Rot of Some Vegetables in Swabi, Khyber Pakhtunkhwa Pakistan
}

\author{
Gulnaz Parveen $^{1 *}$, Naila Mukhtar ${ }^{2}$, Shumaila Irum ${ }^{3}$ and Nain Bukhari ${ }^{4}$
}

${ }^{1}$ Department of Botany, Women University Swabi, Swabi-23561, Khyber Pakbtunkhwa, Pakistan; ${ }^{2}$ Department of Botany, University of Okara, Okara-56300, Punjab, Pakistan; ${ }^{3}$ Department of Zoology, University of Gujrat, Pakistan; ${ }^{4}$ Department of Clinical Laboratory, Women University Swabi, Swabi-23561, Khyber Pakbtunkhwa, Pakistan.

Abstract | The major global concern of the developing countries is to fulfill the basic need of food to mankind as more than one-third of the food is lost due to various kinds of diseases and many other effects like postharvest loss by different fungi. The danger of post-harvest disease influences the way most horticultural crops are handled. Hence, the proper identification of the causal pathogen is important before appropriate treatment can be made to control the pathogens. Therefore, In the present study, Alternaria alternata,Alternaria, Rhizopus, Mucor, Aspergillus niger, Aspergillus flavus, Cladosporium, Botrytis cinerea, Fusarium moniliforme, Drechslera, Penicillium, and Geotrichum candidum were identified among various vegetables including potato, carrot, okra, eggplant, turnip, cucumber, round gourd, cauliflower, and chilli. These losses result in about a 30\% reduction in the yield of these vegetables. By reducing the post-harvest losses, it could be possible to overcome the need of food as the world population is in dare need of research relating to crop sustainability.

Received | February 07, 2021; Accepted | July 05, 2021; Published | July 13, 2021

*Correspondence | Gulnaz Parveen, Department of Botany, Women University Swabi, Swabi-23561, Khyber Pakhtunkhwa, Pakistan; Email: gulnaz.malik3@gmail.com

Citation | Parveen, G., N. Mukhtar, S. Irum and N. Bukhari. 2021. Incidence of post-harvest fungal rot of some vegetables in Swabi, Khyber Pakhtunkhwa Pakistan. Pakistan Journal of Agricultural Research, 34(3): 632-637.

DOI | https://dx.doi.org/10.17582/journal.pjar/2021/34.3.632.637

Keywords | Losses, Post-harvest, vegetable, Pathogens, Infection

\section{Introduction}

$\mathrm{F}$ ood insecurity is the ultimate result of income and poverty (Tacoli, 2019) which also results in malnutrition and hence affects the world's population (Godfray et al., 2010). Therefore, due to less consumption of fruits and vegetables, mortality is among the top risk factors (Ezzati et al., 2002). Vegetables are the living parts of plant and contain about 65 to $95 \%$ of water (Can et al., 1988). In Pakistan about 36 varieties of vegetables are cultivated on large scale and these vegetable provides a prerequisite for health because they supply the essential nutrients to the body needed for a balanced diet (Gulfam et al., 2020). Moreover, they play an important role in the diet of mostly lower income families.

Most of the countries in last few decades focused on the improvement of agricultural production to overcome the increasing food demand (Kumar and Kalita, 2017). During post-harvest operations, about one third of the food produced is at risk or totally lost globally (Gustavsson et al., 2011). Whereas the term food loss is defined as that the food goes unconsumed even it was available (Buzby et al., 2015). Post-harvest loss can be explained as degradation in volume, value and nutrition (Chitranshi et al., 2020). Considerable amount of food is gone in post-harvest (Faiz et al., 2020). Moreover, the fungi and nematodes are also posing a serious threat to our crops (Parveen et al., 
2020). Fungi is considered to be among the imperative pathogens of plants resulting in huge losses (Gonzalez et al., 2011; Hamon et al., 2011). Due to pest and pathogen attack on vegetable and fruits, Pakistan is no more the fifth larger exporter of the world; among all other pathogens the diseases caused by fungus are more lethal (Hussain and Usman, 2019).

In this context the most common fungi like Alternaria alternata, Alternaria solani, Aspergillus niger, Aspergillus flavus, Fusarium solani, Pencillium spp and Rhizopus stolonifer responsible for post-harvest lost in vegetables were studied in Khyber Pakhtunkhwa especially in Swabi. Post-harvest losses of vegetables occur due to improper harvesting, transportation storage and distribution. The post-harvest losses can be minimizing by adopting necessary culture techniques such as careful handling, packing and the use of appropriate chemicals at pre and post-harvest stages. The current study about reduction in post harvest losses could be helpful for sustainable crop productions.

\section{Materials and Methods}

\section{Sample collection}

Sample of different rotted vegetables like Cucumber, (Cucumis satious) Cauliflower, (Brassica oleracea) Eggplant, (Solanum melongena) Okra, (Hibiscus esculentus) Potato, (Solanum tuberosum), Chili (Capsicum annum), Turnip (Brassica rapa), Carrot (Daucus carrota) and Round gourd (Praecitrullus fistulos) were collected in different season from different market of District Swabi including Tordher and Marghuz. These areas were located in Khyber Pakhtunkhwa province of Pakistan.

\section{Sample preparation}

Rotted vegetables were brought to laboratory in sterile polythene bags. Small pieces (five in number) were cut with sharp razor each of about $1 \mathrm{~cm}$ and transfer into Potato Dextrose Agar (PDA) plates containing penicillin (10000 units $\backslash \mathrm{L})$ and streptomycin $(0.2 \mathrm{~g} \backslash \mathrm{L})$ and then incubated for 5 days at room temperature. After 5 to 7 days' pathogens were identified on the basis of their color, colony structure, growth of pathogens, spores and mycelium structure (Reddy et al., 2014).

\section{Experimental work}

These cultures then purified by "single spore isolation method" these pure cultures were maintained on PDA slants for further study. Pure cultures were obtained by observing the following characteristics like, colony characteristics, biochemical properties, morphology, staining reaction etc.

\section{Results and Discussion}

Different types of rotting vegetables such as Cucumber (Cucumis satious), Cauliflower (Brassica oleracea), Eggplant (Solanum melongena), Potato (Solanum tuberosum), Okra (Hibiscus esculentus), Carrot (Daucus carota), Chili(Capsicumannum), Turnip (Brassicarapa), Round gourd (Praecitrulus fistulosa) were collected from two markets of Swabi including Tordher and Marghuz. In this study carrot (Daucus carota) was infected by Aspergillus flavus, Geotrichum candidum, Rbizopus stolonifer and Alternaria alternata (Table 1; Figure 1) and Cucumber (Cucumis satious) was infected by Alternaria alternata, Rhizopus, Alternaria solani, Botrytis cinerea, Aspergillus niger, Pencillium, Fusarium moniloforme (Table 1; Figure 2), Eggplant (Solanum melongena) was affected by Aspergillus flavus, Aspergillus niger, Cladosporium, Alternaria alternata and Rhizopus (Table 1; Figure 3), Chili was infected by Alternaria solani, Aspergillus terreus, Mucur, Botrytis cinerea (Table 1; Figure 4). The microscopic structure of Rhizopus causing disease in Cucumber, Turnip and Round gourd was also shown (Figure 5) and the structure of Alternaria alternata causing disease in Cauliflower, Eggplant and Round gourd were observed (Figure 6). Potato (Solanum tuberosum) was identified to be infected by Aspergillus niger, Cladosporium, Fusarium moniliforme and Alternaria solani, Ladyfinger (Hibiscus esculentus) was spoiled by Aspergillus Alavus, Aspergillus niger, Cladosporium and Drechselera (Table 1; Figure 7) and Cauliflower (Brassica oleracea) was infected by Pencillium, Botrytis cinerea, Alternaria alternata, Aspergillus flavus, and Alternaria solani pathogens (Table 1; Figure 8).

Post-harvest losses among fruits and vegetables may occur at any time while handling as the management related to postharvest done to maximize the storage value and quality of vegetables and most of the genera found involved acting as pathogens like Geotrichum, Aspergillus, Penicillium, Alternaria, Fusarium, Phomopisetc (Adaskaveg et al., 2002; Rahul et al., 2015). 
Table 1: Identification of pathogens and disease caused by these pathogens on vegetables.

\section{S. Common Botanical names Pathogens}

\section{Location} No. names

1 Cauliflower Brassica oleraceae

Pencillium, Botrytis cinerea, Aspergillus flavus, Alternaria alternata,

Tordher

2 Cucumber Cucumis sativus Alternaria solani

Aspergillus flavus, Pencillium, Rhizopus, Aspergillus niger, Fusarium moniliforme

3 Ladyfinger Hibiscus esculentus

Aspergillus flavus, Drechselera, Aspergillus niger, Cladosporium

4 Eggplant Solanum melongena

5 Potato Solanum tuberosum

Aspergillus flavus, Aspergillusniger, Cladosporium, Alternaria alternate

Fusarium moniliforme, Cladosporium, Aspergillus niger

6 Carrot

Daucus carota

7 Capsicum

Capsicum annuum

Alternaria alternata, Aspergillus flavus, Rbizopus stolonifer, Geotrichum candidum

8 Turnip Brassica rapa

Alternaria, Aspergillus flavus, Mucur, Botrytis cinerea

9 Round gourd Praecitrullus fistulosa Alternaria solani, Rhizopus

Rhizopus, Alternaria solani

10 Cauliflower Brassica oleraceae

Pencillium, Botrytis, Aspergillus flavus, Alternaria alternata, Alternaria

Marghuz solani,

11 Cucumber Cucumis sativus Aspergillus flavus, Botrytis cinerea, Rhizopus

12 Ladyfinger Hibiscus esculentus

13 Eggplant Solanum melongena

Aspergillus flavus, Drechselera Aspergillus niger, Cladosporium

14 Potato

Solanum tuberosum

Aspergillus flavus, Aspergillus niger, Cladosporium, Alternaria alternate

15 Carrot

Daucus carrota

16 Capsicum

Capsicum annuum

17 Turnip

Brassica Rapa

18 Round gourd Praecitrullus fistulosa Alternaria solani ,Fusarium moniliforme, Cladosporium Aspergillus niger Aspergillus flavus, Rhizopus stolonifer Alternaria solani, Aspergillusterreus, Mucur, Botrytis cinerea, Alternaria solani, Rhizopus

Rbizopus, Alternaria solani, Alternaria alternate

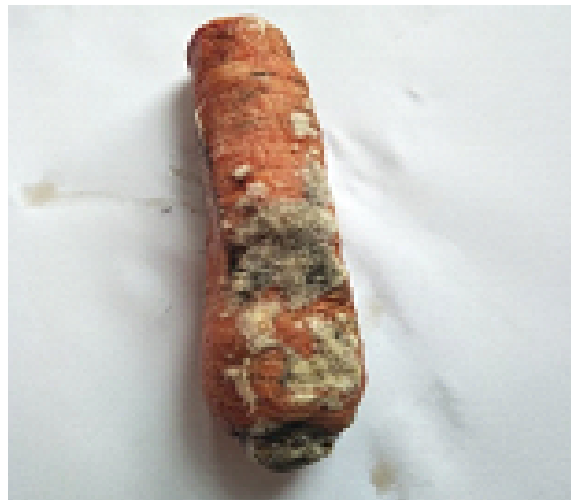

Figure 1: Alternaria alternata showing symptoms on Carrot.



Figure 2: Fusarium moniliforme identified on Cucumber.

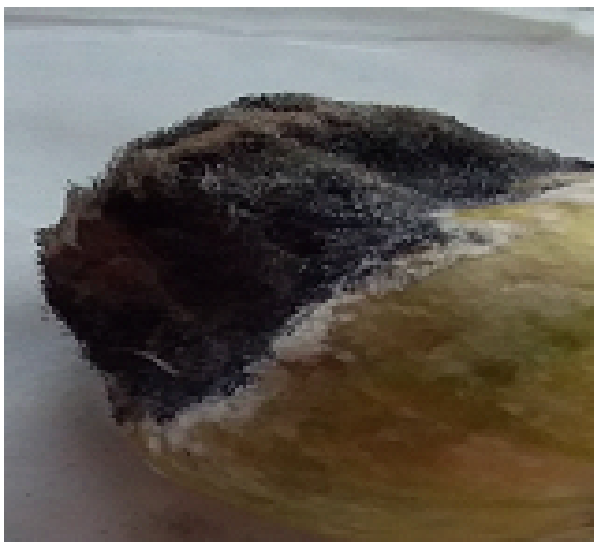

Figure 3: Rhizopus showing disease symptoms on Round Gourd.

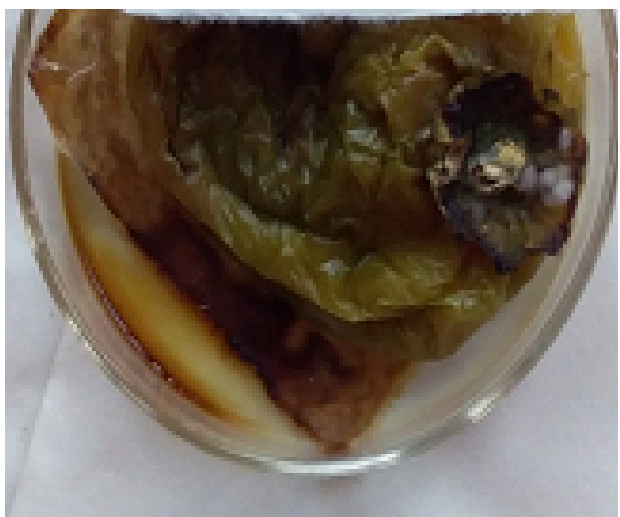

Figure 4: Botrytis cinerea identified on Chili. 


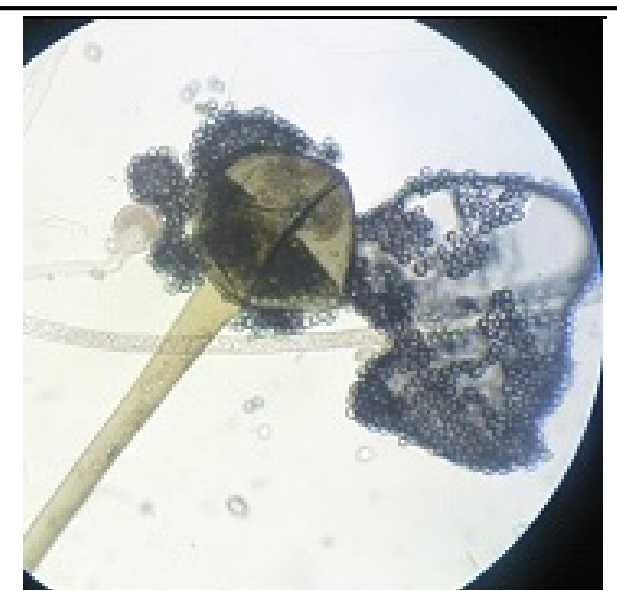

Figure 5: Microscopic structure of Rbizopus to cause disease on Cucumber, Turnip and Round gourd

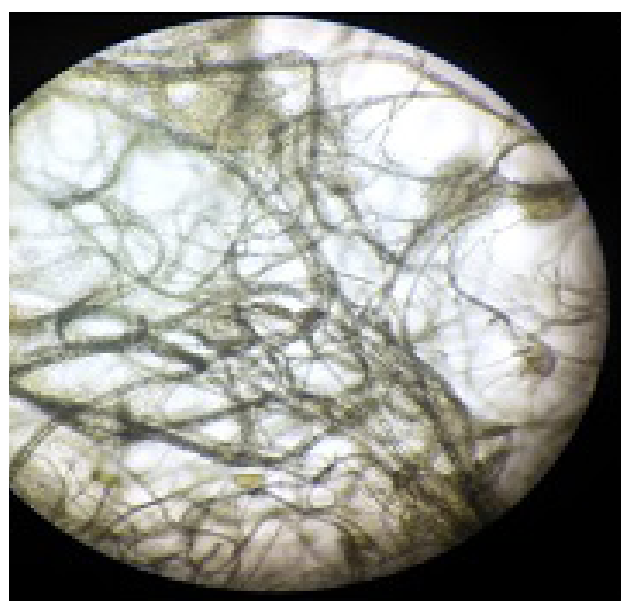

Figure 6: Microscopic structure of Alternaria alternata to cause disease on Cauliflower, Eggplant and Round gourd.

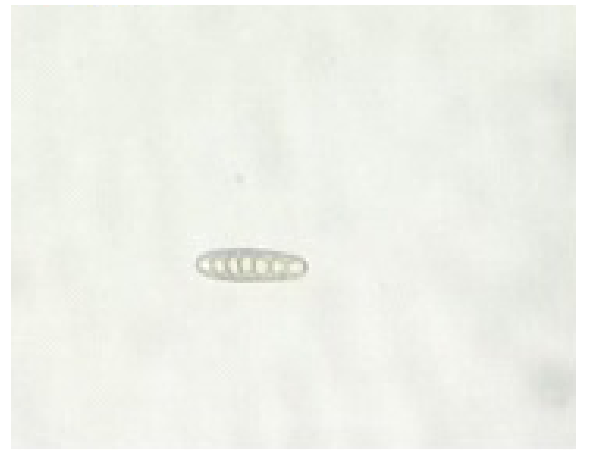

Figure 7: Microscopic structure of Drechselera to cause disease on Ladyfinger.

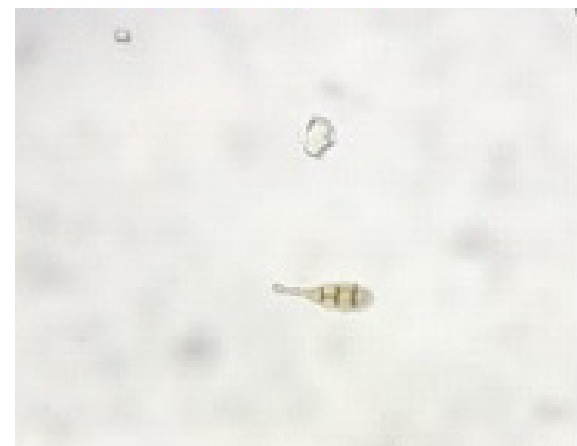

Figure 8: Microscopic structure of Alternaria solani to cause disease on Round gourd, Potato and Cauliflower.
In this study Alternaria alternata, Rbizopus, Alternaria solani, Botrytis cinerea, Aspergilus niger, Pencillium, Fusarium moniloforme were found to be associated with Cucumber whereas Fatima et al. (2009) worked on the same vegetable and identified Cladosporium, Cladosporioides, Fusarium solani, Geotrichum candidum. The Cauliflower (Brassica oleracea) was infected by Pencillium, Botrytis cinerea, Alternaria alternata, Aspergillus flavus, and Alternaria solani pathogens and according to Enyiukwu et al. (2014), species of Aspergillus, Fusarium, Colletotrichum, Pencillium, and Rbizopus are the pathogen that participates in post-harvest rots of horticultural products. The Eggplant (Solanum melongena) was infected by Aspergillus flavus, Aspergillus niger, Cladosporium, Alternaria alternata and Rbizopus while Hausbeck et al. (2008) studied eggplant (Solanum melongena) and tomato (Lycopersicon esculentum) and observed that Phytophthora capsici was the infectious cause. The Potato (Solanum tuberosum) was infected by Alternaria niger, Cladosporium, Fusarium moniliforme and Alternaria solani. Whereas Species of Alternaria, Fusarium, Pencillium, Aspergillus, Geotrichum as well as Botrytis have been reported as common postharvest fungi (Splittstoesser, 1987; Adaskaveg et al., 2002). The Okra (Hibiscus esculentus) was spoiled by Aspergillusflavus, Aspergillus niger, Cladosporium and Drechselera. The Carrot (Daucus carota) was infected by Aspergillus flavus, Geotrichum candidum, Rhizopus stolonifer, and Alternaria alternata.

\section{Conclusions and Recommendations}

It is very important to identify the post-harvest fungal pathogens that are responsible to cause diseases in vegetables and ultimately reduce the yield which can decrease the economy of Pakistan. It is much important to develop the awareness and biocontrol agent to overcome the diseases of fungi.

\section{Acknowledgements}

Special thanks to Women University Swabi KP Pakistan to provide the financial support.

\section{Novelty Statement}

In post-harvest losses that species of fungi is vary in different areas due to environmental factor while in the area of Swabi Khyber-Pakhtunkhwa it was first time reported that different vegetables have become 
destroyed due to less awareness, lacking of diagnostic measurement and precaution of its post-harvest losses.

\section{Author's Contribution}

GP: Conceived and designed the experiments.

NM: Analyzed the data.

GP, NM, NB and SI: Wrote the paper.

\section{List of abbreviation}

KP: Khyber PakhtunKhwa; PDA: Potato Dextros Agar; Spp: Species; GP: GulnazParveen; NM: Naila Mukhtar; NB: Nain Bukhari; SI: ShamailaIrum

\section{Availability of data and materials}

The data sets used and/or analyzed during the current study are available from the corresponding author on reasonable request.

\section{Conflict of interest}

The authors have declared no conflict of interest.

\section{References}

Adaskaveg, J.E., H. Forster and N.F. Sommer. 2002. Principles of post-harvest pathology and management of decays of edible horticultural crops. In: Post-harvest Technology of Horticultural Crops, (Eds.): A.A. Kader. Vol. 3311. University of California Publication, California, pp. 163-195.

Buzby, J.C., H. Farah-Wells and J. Hyman. 2015. The estimated amount, value, and calories of postharvest food losses at the retail and consumer levels in the United States. Available online: https://papers.ssrn.com/sol3/. https:// doi.org/10.2139/ssrn.2501659

Canet, W., 1988. Determination of the moisture content of some fruits and vegetables by microwave heating. J. Microw. Power Electromag. Energy, 23: 231-235. https://doi. org/10.1080/08327823.1988.11688062

Chitranshi, S., N. Dubey and M. Sajjad. 2020. Sustainable botanical products for safe postharvest management of perishable produced: A review. J. Hortic. Postharv. Res., 3: 125-140.

Enyiukwu, D.N., A.N. Awurum and J.A. Nwaneri. 2014. Efficacy of plant-derived pesticides in the control of myco-induced postharvest rots of tubers and agricultural products: A review: Net. J. Agric. Sci., 2: 30-46. https://doi. org/10.15580/GJMA.2014.3.0521014241

Ezzati, M., A.D. Lopez, A. Rodgers, S. VanderHoorn and C.J.L.Murray. 2002. Selected major risk factors and global and regional burden of disease. Lancet, 360: 1347-1360. https://doi. org/10.1016/S0140-6736(02)11403-6

Faiz, A.H., Fakhar-i-Abbas, M. Hassan and L.Z. Faiz. 2020. Distribution and abundance of vertebrate pests of cultivated maize and their eco-friendly management in District Bagh, Azad Jammu and Kashmir. Pak. J. Zool., 52: 409-412. https://doi.org/10.17582/journal. pjz/2020.52.1.sc11

Fatima, N.H., V. Batool, J. Sultana and S.E. Haque. 2009. Prevalence rot of vegetables and fruits in Karachi Pakistan. Pak. J. Bot., 41: 3185-3190.

Godfray, H.C.J., J.R. Beddington and I.R. Crute. 2010. Food security: the challenge of feeding 9 billion people. Science, 327: 812-818. https:// doi.org/10.1126/science.1185383

Gonzalez, M., M. Pujal, J.P. Metraux, V. Garcia and M.D. Bolton. 2011. Tobacco leaf spot and root rot caused by Rbizoctonia solani Kuhn. Mol. Plant Pathol., 12(3): 209-216. https://doi. org/10.1111/j.1364-3703.2010.00664.x

Gulfam, H., A. Ijaz, I.M. Qavi, Z. Shafiq-uRehman, and I. Muhammad. 2020. Strengths and weaknesses of trainings imparted to periurban vegetable growers in the Punjab-Pakistan. Sarhad J. Agric., 36: 224-229.

Gustavsson, J., C. Cederberg, U. Sonesson, R. VanOtterdijk and A. Meybeck. 2011. Global food losses and food waste; food and agriculture organization of the United Nations: Rome, Italy.

Hamon, C., A. Beranger, C.J. Coyne, R.J. Mcgee and I.L. Golf. 2011. New consistent QTL in pea associated with partial resistance to Aphanomyces euteiches in multiple field and controlled environment from France and the United States. Theor. Appl. Genet., 123(2): 261-281. https://doi.org/10.1007/s00122-011$1582-z$

Hausbeck, M.K., A.P. Keinath, C.S. Kousik and M.E.Matheron. 2008.Managing Phytophthora disease with fungicides. Phytopathol. APS Centennial celebration in Minneapolis, MN. July 26.

Hussain, F. and F. Usman. 2019. Fungal biotic 
stresses in plants and its control strategy. Abiotic and Biotic Stress in plants. https://doi. org/10.5772/intechopen.83406

Kumar,D. and P. Kalita. 2017. Reducing postharvest losses during storage of grain crops to strengthen food security in developing countries. Foods, 6: 1-22. https://doi.org/10.3390/foods6010008

Parveen, G., F. Urooj, S. Moin, H. Farhat, M.F. Fahim and S. Ehteshamul-haque. 2020. Estimation of losses caused by root rotting fungi and root knot nematodes infecting some important crops in lower Sindh and Hub, Balochistan of Pakistan. Pak. J. Bot., 52: 673678. https://doi.org/10.30848/PJB2020-2(15)

Rahul, S.N., K. Khilari, S. Sagar, S. Chaudhary, S. Kumar,N.Vihan and A.Tomar.2015.Challenges in postharvest management of fungal diseases in fruits and vegetables. A review. South Asian J. Food Technol. Environ., 1: 126-130. https:// doi.org/10.46370/sajfte.2015.v01i02.04

Reddy, P.L.N., B.S. Babu, A. Radhaiah and A. Sreeramulu. 2014. Screening, identification and isolation of cellulolytic fungi from soils of Chittoor District, India. Int. J. Curr. Microbiol. Appl. Sci., 3: 761-771.

Splittstoesser, D.F., 1987. Fruits and fruit products. In: Food and Beverage Mycology. (Ed.): L. Beuchat. Van Nostrand Reinhold, New York. pp. 101-128.

Tacoli, C., 2019. Editorial: The urbanization of food insecurity and malnutrition. Environ. Urban, 31: 371-374. https://doi. org/10.1177/0956247819867255 